$\xi=$ 줄

\title{
Efficacy of various administrative techniques of methylprednisolone on oedema, trismus and pain after lower third molar surgery
}

\author{
Vaibhav Mukund ${ }^{1 *}$, Sanjeev Kumar ${ }^{2}$, Sukumar Singh ${ }^{3}$, Rishi Rath ${ }^{4}$, Siddharth Tevatia $^{5}$ \\ ${ }^{1}$ MDS, Department of Oral and Maxillofacial Surgery, I.T.S. Centre for Dental Studies and Research, Delhi-Meerut Road, Ghaziabad \\ ${ }^{2}$ Professor and H.O.D, Department of Oral, Maxillofacial Surgery \& Implantology, I.T.S-Centre for Dental Studies \& Research, \\ Ghaziabad \\ ${ }^{3}$ Reader, Department of Oral, Maxillofacial Surgery \& Implantology, I.T.S-Centre for Dental Studies \& Research, Ghaziabad \\ ${ }^{4}$ Professor and Head, Department of Pharmacology, I.T.S. - Centre for Dental Studies \& Research, Ghaziabad \\ ${ }^{5}$ MDS, Department of Periodontology \& Oral Implantology, I.T.S. Centre for Dental Studies and Research, Delhi-Meerut Road, \\ Ghaziabad \\ *Corresponding author E-mail:
}

\begin{abstract}
Due to their anatomical position, the surgical removal of impacted third molars results in oedema, pain, and trismus. The purpose of this study was to evaluate the efficacy of four different routes of administration of methylprednisolone on oedema, trismus and pain after lower third molar surgery. This randomized, perspective, and controlled study included 150 patients. The patients were randomly divided into five groups: Group A (control; no steroids), Group B (Submucosal injection), Group C (oral tablets), Group D (i.v. injection) and Group E (Intramuscular Injection). On days 2 and 7 following surgery, linear oedema was determined using facial landmarks, and maximal mouth opening was measured. Postoperative mouths opening and swelling were evaluated for each route of methylprednisolone administration and compared. The female (59\%) to male (41\%) ratio was 1.44 ; the mean age of the patients was 29.6 years. The level of significance was set at $\mathrm{P}<0.01$ for mouth opening and $\mathrm{P}<0.05$ for oedema. With regard to trismus, all four routes of administration demonstrated better efficacy in comparison to the control. While oral administration and i.v. injection of methylprednisolone achieved similar results, masseter injection provided better results in reducing oedema and trismus when compared with the control following lower third molar surgery.
\end{abstract}

Keywords: Use about five key words or phrases in alphabetical order, Separated by Semicolon

\section{Introduction}

The physiological response from the body tissues to injury from any cause is inflammation and pain, which vary for each patient. After every surgical intervention, inflammatory mediators (prostaglandins, leukotrienes, bradykinin, platelet activating factor, etc.) are released into the tissues in response to this irritation, with a subsequent increase in vascular dilatation and permeability, causing oedema and enhancing the interstitial tissue response(Bamgbose et al.2005 \& Laureano et al 2008).

Surgical removal of the mandibular third molars is the most common surgical procedure in oral and maxillofacial surgery. Due to the anatomical position of impacted third molars, both soft and hard tissue trauma occurs during surgery, resulting in postoperative oedema and trismus (Kulkarni et al 2011). Therefore, the control of postoperative inflammation by any means will increase patient comfort. With regard to the pharmacological approach, there are various strategies for minimizing the clinical manifestations after surgery by inhibiting the synthesis and/or release of the inflammatory mediators of acute inflammation. A reduced level of mediators at the site of tissue injury will lessen the increase in vascular permeability (Bamgbose et al.2005). As a result, interstitial fluid accumulation and tissue pres-sure will be decreased. For the last 60 years, non-steroidal anti-inflammatory drugs (NSAIDs), various steroids, enzymes, and antihistamines have been used to reduce postoperative complications (Kulkarni et al 2011). Steroids acting as immune suppressors block both the early and late stages of the inflammation process. Corticosteroids have an inhibitory action on the enzyme phospholipase A2, which reduces the release of arachidonic acid to the site of inflammation. Thus, the synthesis of prostaglandins and leukotrienes and also the accumulation of neutrophils are reduced (Hirschman 1986). Various corticosteroids such as betamethasone, triamcinolone, prednisolone, hydrocorti-sone, dexamethasone, methylpredniso-lone, etc., are prescribed to control pain, trismus, and swelling (Ustun et al 2003). The aim of this study was to compare the efficacy of four different routes of administration of methylprednisolone on oedema and trismus after impacted lower third molar surgery.

\section{Materials and methods}

This clinical study included 150 patients aged between 18 and 45 years (mean 29.6 years) who required removal of an impacted lower third molar and who were free of inflam-matory symptoms. Patients who applied to the study clinic from September 2015 to august 2016 were assessed in terms of the study inclusion criteria. 
Patients were randomized to one of five study groups by the surgeon, who selected opaque envelopes on which the names of the patients were written. The first 30 patients constituted the control group (group A). The remaining 120 patients were assigned to four further groups, with 11 patients in each: local injection of methylprednisolone (group B), oral methylprednisolone tablet (group C), and intravenous (i.v.) methyl-prednisolone injection (group D), intramuscular (i.m.) methyl-prednisolone injection (group E). This study was approved by the institutional ethics committee and was carried out in accordance with the Declaration of Helsinki on medical protocol and ethics. All patients were recruited into the study upon request. Certain clinical criteria were used for standardization. Inclusion criteria were as follows: age between 18 and 45 years; no systemic disease; totally impacted mandibular third molars of class $\mathrm{C}, 1,2$, and 3 according to the Pell-Gre-gory classification. 1 In our clinic we perform the removal of an impacted tooth on the basis of evidence; teeth were extracted for various indications, such as pre-orthodontic preparation, prevention of post-orthodontic relapse, preparation for orthognathic surgery, prevention of second molar damage, and follicular expansion to rule out possible odontogenic cyst or tumour formation. Exclusion criteria were the following: the use of medications that could interfere with the healing process, smoking, and pregnancy or lactation. Group A patients (control group) received no preoperative or postoperative anti-inflammatories or steroids. Group B patients received a single dose of methyl- prednisolone $20 \mathrm{mg} / \mathrm{ml}$ by parenteral route (injection) into the masseter muscle; this was done via intra-buccal approach in the immediate postoperative period, directly after suturing of the surgical wound. Group $\mathrm{C}$ patients received a single $20-\mathrm{mg}$ dose of methylprednisolone in the form of an oral tablet taken $1 \mathrm{~h}$ before the procedure. Group D patients received a single dose of methylprednisolone $20 \mathrm{mg} / \mathrm{ml}$ i.v. in the immediate postoperative period. Group $\mathrm{E}$ patients received a single dose of methylprednisolone $20 \mathrm{mg} / \mathrm{ml} \mathrm{i.m.} \mathrm{in} \mathrm{the}$ immediate postoperative period.

Surgical procedure all patients were free of inflammatory symptoms in the oral cavity at the time of surgery and were operated on by the same surgeon using a standard technique; mouthwash with $0.2 \%$ chlorhexidine was given prior to local anaesthesia. Local anaesthesia of the inferior alveolar nerve and lingual nerve, and terminal infiltration of the buccal fold was performed using $2 \%$ lidocaine hydrochloride and 1:200,000 adrenaline. Only one third molar was removed from each patient, hence a total of 150 teeth were extracted. Surgical access was standardized and involved a linear incision on the alveolar ridge aligned with the buccal region of the second molar, combined with a $1-\mathrm{cm}$ ver-tical incision. A standard triangular flap and the retentive bone around the third molar were removed under irrigation with $0.9 \%$ saline solution. After the extraction was completed, irregular bone borders were removed, and the alveolus was irrigated with $10 \mathrm{ml} 0.9 \%$ saline solution. The surgical site was sutured with $3-0$ silk. All patients received standard post-operative instructions. Antibiotics (amoxicillin and clavulanic acid $1 \mathrm{~g}$ oral tablets; one tablet every $12 \mathrm{~h}$ ) and $0.2 \%$ chlorhex-idine gluconate solution were prescribed for 5 days. The intraoral sutures were removed on postoperative day 7 . Data collection Trismus and swelling were evaluated in comparison to the preoperative values Baseline (time 1) on day 2 (time 2) and day 7 (time 3 ) following the surgical procedure.

Oedema was evaluated using three facial lines

1) The distance from the external canthus of the eye (A) to the gonion angle (B).

2) The distance from the lower border of the tragus (C) to the mouth commissure on the operated side (D)

3) The distance from the lower border of the tragus (C) to the soft pogonion. (E)

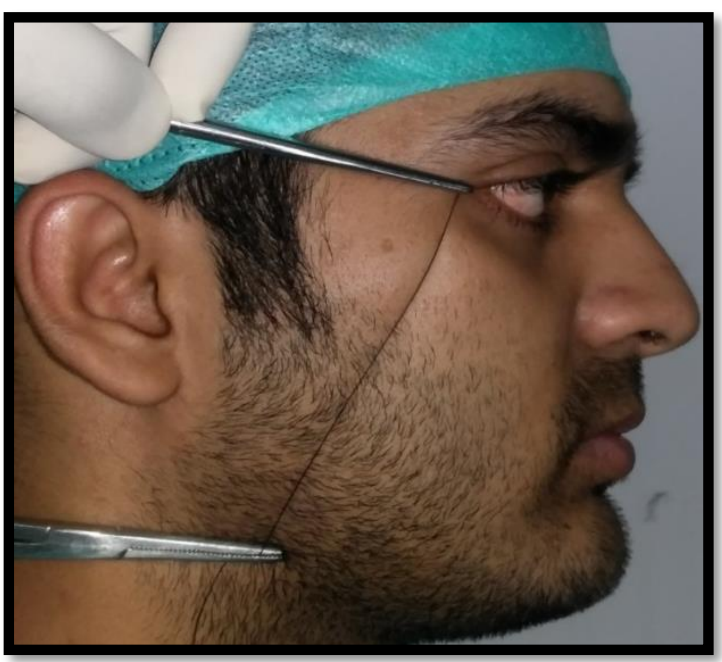

Fig 1: Measurements between Points A and B.

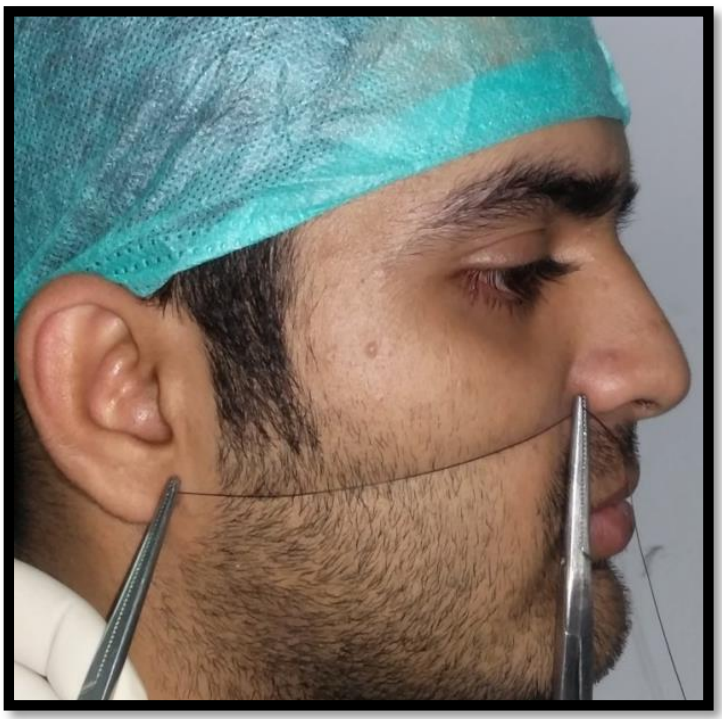

Fig. 2: Measurements between Points A and D.

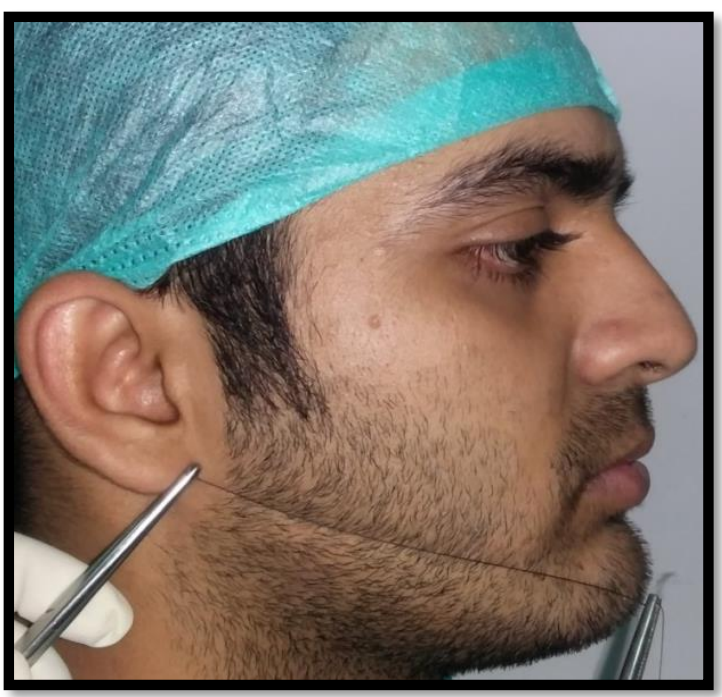

Fig. 3: Measurements between Points A and E.

Trismus was evaluated by measuring the Inter-incisal Opening at maximum opening (as shown in figure 4) of the jaws recorded preoperatively and on the second and seventh postoperative days in both the groups. 


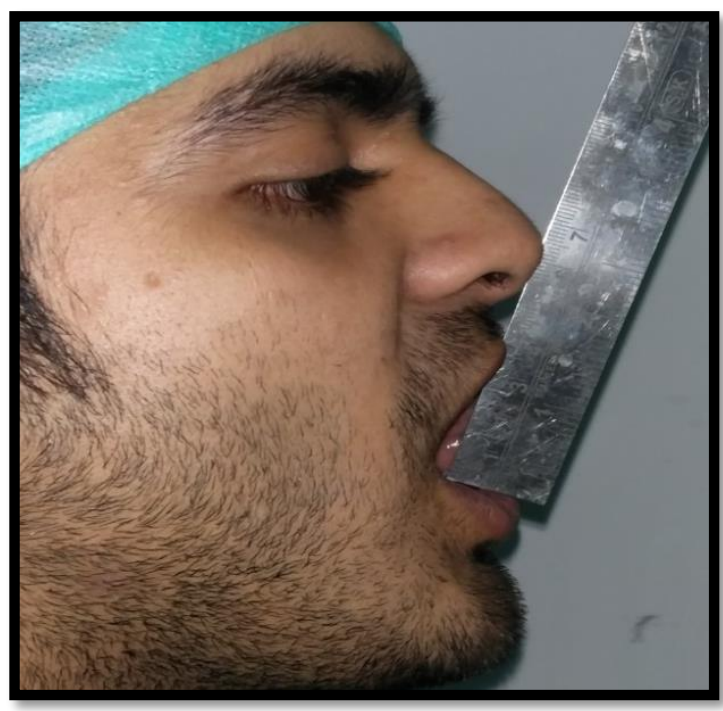

Fig. 4: Measurement of Trismus by Measuring the Interincisal Distance.

\section{Statistical analysis}

Statistical analysis was carried out using Statistical Package for Social Sciences (SPSS Inc., Chicago, IL, version 16.0 for windows). Test for qualitative variables, mean and standard deviation were calculated. All the clinical parameters were recorded at baseline, $2^{\text {nd }}$ and $7^{\text {th }}$ day post operatively and subjected to statistical analysis. Comparison of all variables (Oedema, trismus, Pain) between the groups was performed. Mean change was determined and compared across the control and test groups. Swelling, truisms and pain score (VAS) were compared statistically between the groups using one way ANOVA and post-hoc Bonferroni test.

\section{Results}

\subsection{Postoperative swelling score}

Intra-group comparison on $2^{\text {nd }}$ day the comparison of mean swelling score at day 2 was done between groups A, B, C, D and E using the one-way ANOVA test. There was a significant difference in mean swelling score at day 2 between groups A, B, C, D and $\mathrm{E}$. (Table 1). The comparison of mean swelling score at day 7 was done between groups $\mathrm{A}, \mathrm{B}, \mathrm{C}, \mathrm{D}$ and $\mathrm{E}$ using the one-way ANOVA test. There was no significant difference in mean swelling score at day 7 between groups A, B, C, D and E. (Table 2)

Table 1: Comparison of Mean Swelling Score at $2^{\text {nd }}$ Day in Test and Control Groups

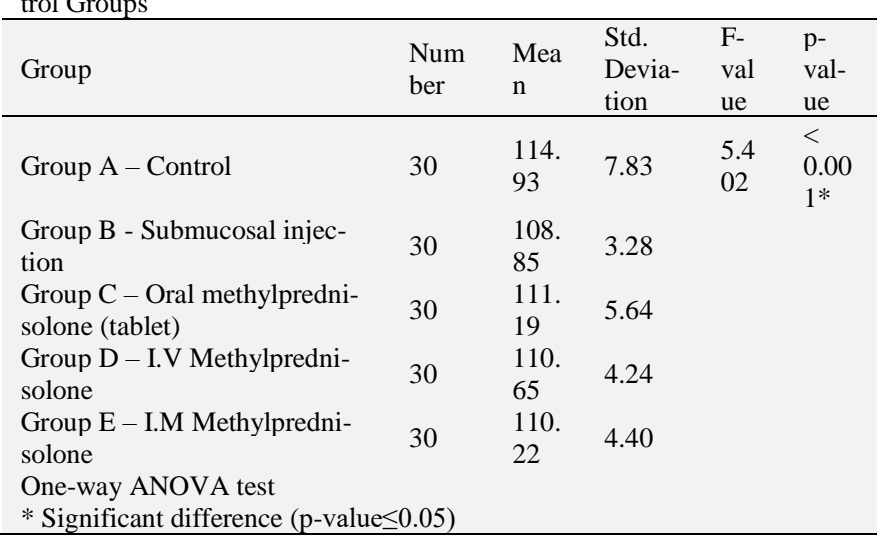

* Significant difference ( $\mathrm{p}$-value $\leq 0.05$ )
Table 2: Comparison of Mean Swelling Score at $7^{\text {th }}$ Day in Test and Control Groups

\begin{tabular}{|c|c|c|c|c|c|}
\hline Group & $\begin{array}{l}\text { Num } \\
\text { ber }\end{array}$ & $\begin{array}{l}\text { Mea } \\
\mathrm{n}\end{array}$ & $\begin{array}{l}\text { Std. } \\
\text { Devia- } \\
\text { tion }\end{array}$ & $\begin{array}{l}\text { F- } \\
\text { val } \\
\text { ue } \\
\end{array}$ & $\begin{array}{l}\mathrm{p}- \\
\text { val- } \\
\text { ue } \\
\end{array}$ \\
\hline Group A - Control & 30 & $\begin{array}{l}107 . \\
73\end{array}$ & 6.95 & $\begin{array}{l}1.0 \\
51\end{array}$ & $\begin{array}{l}0.38 \\
3^{\#}\end{array}$ \\
\hline $\begin{array}{l}\text { Group B - Submucosal injec- } \\
\text { tion }\end{array}$ & 30 & $\begin{array}{l}105 . \\
33\end{array}$ & 3.86 & & \\
\hline $\begin{array}{l}\text { Group C - Oral methylpredni- } \\
\text { solone (tablet) }\end{array}$ & 30 & $\begin{array}{l}107 . \\
23\end{array}$ & 4.91 & & \\
\hline $\begin{array}{l}\text { Group D - I.V Methylpredni- } \\
\text { solone }\end{array}$ & 30 & $\begin{array}{l}106 . \\
25\end{array}$ & 4.21 & & \\
\hline $\begin{array}{l}\text { Group E - I.M Methylpredni- } \\
\text { solone }\end{array}$ & 30 & $\begin{array}{l}106 . \\
90\end{array}$ & 3.99 & & \\
\hline
\end{tabular}

\subsection{Trismus score}

Intra-group comparison of mean trismus score at day 2 was done between groups A, B, C, D and E using the one-way ANOVA test. There was no significant difference in mean trismus score at day 2 between groups A, B, C, D and E. (Table 3). The comparison of mean trismus score at day 7 was done between groups A, B, C, D and $\mathrm{E}$ using the one-way ANOVA test. There was no significant difference in mean trismus score at day 7 between groups A, B, C, D and E. (Table 4)

Table 3: Comparison of Mean Trismus Score at $2^{\text {nd }}$ Day in Test and Control Groups

\begin{tabular}{|c|c|c|c|c|c|}
\hline Group & $\begin{array}{l}\text { Num- } \\
\text { ber }\end{array}$ & $\begin{array}{l}\text { Mea } \\
n\end{array}$ & $\begin{array}{l}\text { Std. } \\
\text { Devia- } \\
\text { tion }\end{array}$ & $\begin{array}{l}\text { F- } \\
\text { val- } \\
\text { ue }\end{array}$ & $\begin{array}{l}\text { p- } \\
\text { val- } \\
\text { ue }\end{array}$ \\
\hline Group A - Control & 30 & $\begin{array}{l}37.8 \\
7\end{array}$ & 4.36 & $\begin{array}{l}1.06 \\
3\end{array}$ & $\begin{array}{l}0.37 \\
7^{\#}\end{array}$ \\
\hline $\begin{array}{l}\text { Group B - Submucosal injec- } \\
\text { tion }\end{array}$ & 30 & $\begin{array}{l}36.5 \\
2\end{array}$ & 2.21 & & \\
\hline $\begin{array}{l}\text { Group C - Oral methylpred- } \\
\text { nisolone } \\
\text { (tablet) }\end{array}$ & 30 & $\begin{array}{l}37.0 \\
0\end{array}$ & 2.82 & & \\
\hline $\begin{array}{l}\text { Group D - I.V Methylpred- } \\
\text { nisolone }\end{array}$ & 30 & $\begin{array}{l}36.6 \\
6\end{array}$ & 2.76 & & \\
\hline $\begin{array}{l}\text { Group E - I.M Methylpred- } \\
\text { nisolone }\end{array}$ & 30 & $\begin{array}{l}36.4 \\
7\end{array}$ & 2.71 & & \\
\hline \multicolumn{6}{|c|}{$\begin{array}{l}\text { One-way ANOVA test } \\
\text { "Non-significant difference (p-value >0.05) }\end{array}$} \\
\hline
\end{tabular}

Table 4: Comparison of Mean Trismus Score at $7^{\text {th }}$ Day in Test and Control Groups

\begin{tabular}{|c|c|c|c|c|c|}
\hline Group & $\begin{array}{l}\text { Num- } \\
\text { ber }\end{array}$ & $\begin{array}{l}\text { Mea } \\
n\end{array}$ & $\begin{array}{l}\text { Std. } \\
\text { Devia- } \\
\text { tion }\end{array}$ & $\begin{array}{l}\text { F- } \\
\text { val- } \\
\text { ue }\end{array}$ & $\begin{array}{l}\text { p- } \\
\text { val- } \\
\text { ue }\end{array}$ \\
\hline Group A - Control & 30 & $\begin{array}{l}42.1 \\
7\end{array}$ & 4.48 & $\begin{array}{l}1.23 \\
5\end{array}$ & $\begin{array}{l}0.29 \\
9^{\#}\end{array}$ \\
\hline $\begin{array}{l}\text { Group B - Submucosal injec- } \\
\text { tion }\end{array}$ & 30 & $\begin{array}{l}40.6 \\
2\end{array}$ & 1.37 & & \\
\hline $\begin{array}{l}\text { Group C - Oral methylpred- } \\
\text { nisolone } \\
\text { (tablet) }\end{array}$ & 30 & $\begin{array}{l}41.2 \\
9\end{array}$ & 2.49 & & \\
\hline $\begin{array}{l}\text { Group D - I.V Methylpred- } \\
\text { nisolone }\end{array}$ & 30 & $\begin{array}{l}41.0 \\
3\end{array}$ & 2.35 & & \\
\hline $\begin{array}{l}\text { Group E - I.M Methylpred- } \\
\text { nisolone } \\
\text { One-way ANOVA test } \\
{ }^{*} \text { Non-significant difference (p }\end{array}$ & alue> & $\begin{array}{l}41.2 \\
0\end{array}$ & 2.16 & & \\
\hline
\end{tabular}

\subsection{Pain score}

Intragroup comparisonof mean pain score at day 2 was done between groups A, B, C, D and E using the one-way ANOVA test. There was no significant difference in mean pain score between groups A, B, C, D and E. (Table 5). The comparison of mean pain score at day 7 was done between groups A, B, C, D and E using the one-way ANOVA test. There was a significant difference in 
mean pain score at day 7 between groups A, B, C, D and E. (Table6).

Table 9: Comparison of Mean Pain Score at $2^{\text {nd }}$ Day in Test and Control Groups

\begin{tabular}{llllll}
\hline Group & $\begin{array}{l}\text { Num- } \\
\text { ber }\end{array}$ & $\begin{array}{l}\text { Mea } \\
\mathrm{n}\end{array}$ & $\begin{array}{l}\text { Std. } \\
\text { Devia- } \\
\text { tion }\end{array}$ & $\begin{array}{l}\text { F- } \\
\text { val- } \\
\text { ue }\end{array}$ & $\begin{array}{l}\text { p- } \\
\text { val- } \\
\text { ue }\end{array}$ \\
\hline $\begin{array}{l}\text { Group A - Control } \\
\text { Group B - Submucosal injec- }\end{array}$ & 30 & 4.30 & 1.39 & 0.14 & 0.96 \\
$5^{\#}$ \\
$\begin{array}{l}\text { tion } \\
\begin{array}{l}\text { Group C - Oral methylpred- } \\
\text { nisolone } \\
\text { tablet) }\end{array}\end{array}$ & 40 & 4.14 & 1.03 & 0.88 & \\
$\begin{array}{l}\text { Group D - I.V Methylpred- } \\
\text { nisolone }\end{array}$ & 30 & 4.14 & 0.88 & \\
$\begin{array}{l}\text { Group E - I.M Methylpred- } \\
\text { nisolone }\end{array}$ & 30 & 4.17 & 0.87 & \\
$\begin{array}{l}\text { One-way ANOVA test } \\
\text { \# Non-significant difference (p-value>0.05) }\end{array}$ & & & \\
\hline
\end{tabular}

Table 11: Comparison of Mean Pain Score at $7^{\text {th }}$ Day in Test and Control Groups

\begin{tabular}{|c|c|c|c|c|c|}
\hline Group & $\begin{array}{l}\text { Num- } \\
\text { ber }\end{array}$ & $\begin{array}{l}\text { Mea } \\
\mathrm{n}\end{array}$ & $\begin{array}{l}\text { Std. } \\
\text { Devia- } \\
\text { tion }\end{array}$ & $\begin{array}{l}\text { F- } \\
\text { val- } \\
\text { ue }\end{array}$ & $\begin{array}{l}\mathrm{p}- \\
\text { value }\end{array}$ \\
\hline Group A - Control & 30 & 1.97 & 1.33 & $\begin{array}{l}4.52 \\
3\end{array}$ & $\begin{array}{l}0.00 \\
2 *\end{array}$ \\
\hline $\begin{array}{l}\text { Group B - Submucosal } \\
\text { injection }\end{array}$ & 30 & 1.10 & 0.82 & & \\
\hline $\begin{array}{l}\text { Group C - Oral methylpred- } \\
\text { nisolone } \\
\text { (tablet) }\end{array}$ & 30 & 1.23 & 0.96 & & \\
\hline $\begin{array}{l}\text { Group D - I.V Methylpred- } \\
\text { nisolone }\end{array}$ & 30 & 1.17 & 0.80 & & \\
\hline $\begin{array}{l}\text { Group E - I.M Methylpred- } \\
\text { nisolone }\end{array}$ & 30 & 1.07 & 0.78 & & \\
\hline $\begin{array}{l}\text { One-way ANOVA test } \\
* \text { Significant difference (p-va }\end{array}$ & $\mathrm{e} \leq 0.05)$ & & & & \\
\hline
\end{tabular}

\section{Discussion}

In the present study, single doses of $20 \mathrm{mg}$ of methylprednisolone were given via four different routes preoperatively before surgical removal of mandibular third molar and compared postoperative swelling; trismus and pain with that of the control group were compared. Generally, the ideal drug possesses only minimum mineralcorticoid action and provides therapeutic activity in the immediate postoperative period, i.e. when the inflammatory reaction is most intense. Milles and Desjardins noted, a significant reduction in swelling (42\% to $19 \%$ decrease) during days $1-3$ after mandibular third molar removal using $16 \mathrm{mg}$ MP orally the evening before surgery and $20 \mathrm{mg}$ MP intravenously immediately prior to surgery, They concluded that higher doses of corticosteroids are generally not necessary to achieve a significant clinical benefit.? Although in many studies a dose of 40-80 mg methylprednisolone has been used to control oedema, they administered methylprednisolone $20 \mathrm{mg}$ by injection taking into account the adverse effects found in these studies (Ustun 2003, Yuasa 2004, Sancho-Puchades 2012).

The spectrum of dosages of steroids and routes of administration is diverging, but there is one well-established consensus throughout most studies. Steroids have to be applied before tissue injury occurs to achieve an adequate tissue level in the immediate postoperative period (Yuasa 2004). Some authors strongly recommend the administration at least $2 \mathrm{~h}$ preoperatively (Sancho-Puchades 2012).

Filho et al. reported administration $1 \mathrm{~h}$ prior to surgery (Filho et al 2008). Huffmann reports a reduced post-interventional facial swelling in patients applying MP (125 mg IV) immediately before mandibular third molar surgery (Huffman 1977).

Methylprednisolone meets these requirements as it has no mineralocorticoid activity, half-life is $12-36$ hours, and it is 5 fold more potent than hydrocortisone (Sancho-Puchades 2012). Steroid medication has proven to be well suited for the treatment of postoperative pain, trismus, and swelling after dental surgical procedures, but perioperative corticosteroid use does carry potential complications. It is associated with the possibility of adrenocortical suppression, in particular, when therapy is long term. Williamson et al (1980) used the 'Metyrapone test' to show that after initial suppression of the pituitary adrenal system, normal function is regained within a week of short term steroid therapy. Based on this evidence, adrenocortical suppression is not a significant problem with short term therapy as used for reduction of swelling in oral surgery. Novak et al. have shown that a single large dose, or a short duration of methylprednisolone, results in no complications. No side effects were reported in his study (Novak et al 1970).

Vegas-Bustamante et al. examined the efficacy of a 40-mg injection of methylprednisolone into the masseter muscle compared with a control group (no injection) on trismus, pain, and oedema in third molar surgery. They found pain and swelling to be more greatly reduced on day 2 and day 7 following surgery in the study group when compared with the control group. However, they concluded that pain is subjective evidence for which an objective result cannot be obtained and so was not evaluated during the study (Vegas Bustamante 2008)

Kocer et al. conducted a study to evaluate the efficacy of supraperiosteal injection of $20 \mathrm{mg}$ of methylprednisolone compared with an $20 \mathrm{mg}$ oral tablet form and $20 \mathrm{mg}$ i.v. injection in the prevention of postoperative pain and oedema associated with inflammation. All three routes of administration demonstrated best efficacy in comparison to the control regarding trismus. While oral administration and i.v. injection of MP achieved similar results, masseter injection provided best results in reducing oedema and trismus when compared with the control following lower third molar surgery. 12 .

Milles et al. conducted an experimental study on reduction of postoperative facial swelling by low-dose methylprednisolone on eleven patients he gave $16 \mathrm{mg}$ of MP orally the evening before surgery, combined with $20 \mathrm{mg}$ MP i.v immediately preoperatively, in a double blind, randomized, crossover study. Facial contour was measured preoperatively and postoperatively and on days 1,2,3,4, and 7 postoperatively. He concluded that the low dose of MP reduces swelling by $42 \%$ at 24 hours and $34 \%$ at 48 hours postoperatively. By the third day, the difference was only $19 \%$. He also concluded that trismus were not affected by this dose of methylprednisolon (Kocer et al 2014).

The inter-group comparison in our present study between the groups in which $20 \mathrm{mg}$ of methylprednisolone was administered through different routes like i.v, i.m, Submucosal and Oral tablet. We found that pre-operative submucosal route shows the better result for oedema, pain and trismus than other routes like i.v, i.m and oral tablet. Though the result is statically non-significant for which large sample size is required. So we conclude that preoperative administration of $20 \mathrm{mg}$ of methyleprednisolene though a submucosal route is found to be more effective than postoperative administration. Our results conceded with the results of Mahood et al and Naiv et al .. However, a similar study of larger sample size is required for further analysis.

\section{References}

[1] Bamgbose BO, Akinwande JA, Adeyemo WL, Ladeinde AL, Arotiba GT, Ogunlewe MO. Effects of co-administered dexamethasone and diclofenac potassium on pain, swel-ling and trismus following third molar surgery. Head Face Med 2005; 7:11. https://doi.org/10.1186/1746-160X-1-11.

[2] Laureano Filho JR, Maurette PE, Allais M, Cotinho M, Fernandes C. Clinical compara-tive study of the effectiveness of two dosages of dexamethasone to control postoperative swelling, trismus and pain after the surgical extraction of mandibular impacted third molars. Med Oral Pathol Oral Cir Bucal 2008; 13:129-32.

[3] Kulkarni D, Kshirsagar K. Comparison of the efficacy of dexamethasone and methylpredni- solone during post-operative period of 
surgi- cal removal of impacted mandibular third molar-a clinical study. JIDA 2011; 5:683-6.

[4] Hirschman JV. Some principles of systemic glucocorticoid therapy. Clin Exp Dermatol 1986; 11:27-33. https://doi.org/10.1111/j.13652230.1986.tb00420.x.

[5] Ustun Y, Erdogan O, Esen E et al. Comparison of the effects of 2 doses of methylprednisolone on pain, swelling, and trismus after third molar surgery. OralSurg Oral Med Oral Pathol Oral Radiol Endod. 2003; 96:535-9. https://doi.org/10.1016/S10792104(03)00464-5.

[6] Yuasa H, Sugiura M. Clinical postoperative findings after removal of impacted mandibular third molars: prediction of postoperative facial swelling and pain based on preoperative variables. Br J Oral Maxillofac Surg. 2004; 42:209-14. https://doi.org/10.1016/j.bjoms.2004.02.005.

[7] Sancho-Puchades M, Valmaseda-Castellón E, Berini-Aytés L, Gay-Escoda C. Quality of life following third molar removal under conscious sedation. Med Oral Patol Oral Cir Bucal. 2012; 17:994-9. https://doi.org/10.4317/medoral.17677.

[8] Filho JRL, Maurette PE, Allais M, Cotinho M, Fernandes C. Clinical comparative study of the effectiveness of two dosages of dexamethasone to control postoperative swelling, trismus and pain after the surgical extraction of mandibular impacted third molars.Med Oral Pathol Oral Cir Bucal. 2008; 13:129-32.

[9] Huffman GG. Use of methylprednisolone sodium succinate to reduce postoperative oedema after removal of impacted third molars. J Oral Surg1977; 35:198-9.

[10] Novak E, Stubbs SS, Seckman CE, Hearron MS. Effects of a single large intravenous dose of methylprednisolone sodium succinate. Clin Pharm 1970; 11:711-7. https://doi.org/10.1002/cpt1970115711.

[11] Vegas Bustamante E, Mico Liorens J, Gargalio Albiol J et al. Efficacy of methylprednisolone injected into the masseter muscle following the surgical extraction of impacted third molars. Int J Oral Maxillofac surg. $\quad 2008 ; \quad 37: 260-63$ https://doi.org/10.1016/j.ijom.2007.07.018.

[12] G. Koc,er, E. Yuce, A. Tuzuner Oncul, O. Dereci, O. Koskan: Effect of the route ofadministration of methylprednisolone on oedema and trismus in impacted lower third molar surgery. Int. J. Oral Maxillofac. $\quad$ Surg. $2014 ; \quad$ 43: https://doi.org/10.1016/j.ijom.2013.11.005.

[13] Milles M, Desjardins PJ. Reduction of postoperative facial swelling by low dose Methylprednisolone: an experimental study. J Oral Maxillofac Surg. 1993; 51:987-91. https://doi.org/10.1016/S02782391(10)80041-2. 